\section{Allocation of Photoassimilates in Bud and Fruit from Different Leaf Nodes of Camellia oleifera}

\author{
Yue Wen \\ Research Centre of Characteristic Fruit Tree, College of Horticulture and \\ Forestry, Xinjiang Agricultural University, 830052, Urumqi, China; Key \\ Laboratory of Silviculture and Conversation, Ministry of Education, Beijing \\ Forestry University, Beijing 100083, PR China
}

Shu-chai Su and Ting-ting Jia
Key Laboratory of Silviculture and Conversation, Ministry of Education,
Beijing Forestry University, Beijing 100083, PR China

Xiang-nan Wang

Hunan Academy of Forestry, Changsha Hunan 410004, PR China

Additional index words. Camellia oleifera, photoassimilates translocation, source-sink relationship, ${ }^{13} \mathrm{C}$-labelling, leaf position

\begin{abstract}
The periods of flower bud differentiation and fruit growth for Camellia oleifera overlap greatly affect the allocation of photoassimilates to flower buds and fruit, resulting in obvious alternate bearing. To export the cause and mitigate alternate bearing of Camellia oleifera, the allocation of photoassimilates to buds and fruit supplied by leaves at different node positions was studied by the addition of labeled ${ }^{13} \mathrm{CO}_{2}$ during the slow fruit growth stage. The fate of ${ }^{13} \mathrm{C}$ photoassimilated carbon was followed during four periods: slow fruit growth (4 hours and 10 days after ${ }^{13} \mathrm{C}$ labeling); rapid growth (63 days after ${ }^{13} \mathrm{C}$ labeling); oil conversion (129 days after ${ }^{13} \mathrm{C}$ labeling); and maturation (159 days after ${ }^{13} \mathrm{C}$ labeling). Photosynthetic parameters and leaf areas of the leaves shared a common pattern (fifth $>$ third $>$ first), and the order of photosynthetic parameters of different fruit growth stages was as follows: oil conversion > maturation > rapid growth > slow growth. The most intense competition between flower bud differentiation and fruit growth occurred during the oil conversion stage. Dry matter accumulation in different sinks occurred as follow: fruit $>$ flower bud $>$ leaf bud. Photoassimilates from the labeled first leaf were mainly translocated to the first flower bud, and the upper buds were always differentiated into flower buds. The photoassimilates from the labeled third leaf were distributed disproportionately to the third flower bud and fruit. They distributed more to the third flower bud, and the middle buds formed either flower or leaf buds. However, the photoassimilates from the labeled fifth leaf were primarily allocated to the fruit that bore on the first node of last year's bearing shoot, and basal buds did not form flower buds. Based on our results, the basal leaves should be retained for a high yield in the current year, and the top leaves should be retained for a high yield in the following year. Our results have important implications for understanding the management of flower and fruit in $C$. oleifera. The thinning of fruit during the on-crop year can promote flower bud formation and increase the yield of $C$. oleifera crops in the following year. During the offyear, more fruit should be retained to maintain the fruit yield. The thinning of middleupper buds could promote more photoassimilates allocate to the fruit.
\end{abstract}

Assimilates mainly refer to carbohydrates produced by photosynthesis that provide the required energy and substrate for the growth and development of plant organs and tissues (Myers and Kitajima, 2007; Osorio et al.,

Received for publication 15 Dec. 2020.

Published online 22 February 2021

This research was funded by the National Key Research and Development Program of China (2019YFD1002401).

S.S. is the corresponding author. E-mail: sushuchai (a)sohu.com.

This is an open access article distributed under the CC BY-NC-ND license (https://creativecommons. org/licenses/by-nc-nd/4.0/). 2014). Assimilates are generally allocated from sources to sinks, which are important constituents of the whole plant system. Function leaves are the main sources for exporting assimilates to sinks, whereas the young leaves are often viewed as strong sinks for assimilates (Grappadelli et al., 1994; Tustin et al., 1992). The sink is the organ that consumes and accumulates assimilates (Cao, 2011), such as seeds, buds, roots, flowers, and fruits. The main sink always changes with plant growth and development. As reported by Fanwoua et al. (2014), during the first 2 weeks after apple bloom, the sinks of young leaves and shoot tips are stronger than young fruits, and the fruit receives most assimilates from the rosette and bourse shoot leaves from 3 to 5 weeks after bloom.

It is well-known that the assimilate transportation and allocation are determined by the strength of the source and sink. The source strength, which is estimated by the product of the source size and activity, appears to be well-recognized and universally accepted to have the capacity to synthesize and transport assimilates to a sink, and the source activity could be directly reflected by photosynthesis. The external environment influences photosynthesis (Greer and Weston, 2010; Muller et al., 2011), and the characteristics of leaves also have significant effects on assimilate translocation (Driever et al., 2014). Leaves at different positions are of different ages, which also influences their photosynthetic capacity, such as the net photosynthesis rate (Proietti et al., 2000) and chlorophyll fluorescence parameters (Wen et al., 2018a). Furthermore, various leaves have different source-sink relationships, resulting in differences in assimilate partitioning and carbon contributions to individual sinks (Preston, 1998). Sink strength is the ability to import photosynthates and represent the competitiveness of importing photoassimilates. In two late-maturing Japanese pear cultivars, the sink strength determined the movement of photosynthates into the fruit sink (Zhang et al., 2005). In general, fruits are considered the strongest sink when many sinks exist at the same time (Barzegar and Nekounam, 2016).

Recently, the focus of assimilate allocation was mainly placed on the field crops (Evers et al., 2010; Liu et al., 2019; Sun et al., 2018). These crops have distinct growth and development stages with a relatively single sink during each stage, resulting in little competition among different sinks, and there was almost no alternate bearing in these crops. To our knowledge, less attention was devoted to the assimilates allocation of woody plants with the following characteristics: time overlap between flower bud differentiation and fruit growth; two metabolic sinks (flower bud and fruit) existing on the same plant at the same time; and flower bud differentiation that affects the fruit yield because of competition for photoassimilates. Therefore, the relationship between assimilate allocation and alternate bearing of woody crops is still not clear.

C. oleifera is a unique woody oil tree in southern China (Zhuang, 2008), and its flower buds and fruit are of great importance to the annual yield; therefore, more photoassimilates should be transported to the flower buds and fruit. However, the periods of flower bud differentiation and fruit growth overlap with no strict time limits (Lei et al., 2017) that greatly affect the allocation of photoassimilates to flower buds and fruit, resulting in alternate bearing of $C$. oleifera. Previous studies have provided details about the photosynthesis and assimilate distribution in source leaves in response to sink-source manipulation (different leaf-to-fruit ratios) (Yuan et al., 2015). However, the 
Table 1. Flower bud characteristics at different morphological stages of C. oleifera flower buds.

\begin{tabular}{|c|c|c|}
\hline Month & Stage & Phenotypic characteristics \\
\hline Late April to early May & Predifferentiation stage & Flower buds had no appearance differences during the early period; slightly wider later \\
\hline Early May to late May & Sepal formation period & $\begin{array}{l}\text { Flower bud was wide and flat during the early period, } \\
\text { turned wider later, clear distinctions between the flower bud } \\
\text { and leaf bud were noted, } 2-3 \text { bracts }\end{array}$ \\
\hline Late May to early June & Petal formation stage & Flower bud was full and dark purple, $3-4$ bracts \\
\hline Early June to late June & Stamen and pistil formation stage & Flower bud was full and elongated and changed from purple to green, $4-5$ bracts \\
\hline Late June to late July & Ovary and anther formation stage & Flower bud size increased dramatically, $5-6$ bracts \\
\hline Late July to mid-September & Stamen and pistil maturation stage & Flower bud was very full and turned from light green to yellow-green, $7-9$ bracts \\
\hline
\end{tabular}

Table 2. Fruit characteristics during the main fruit developmental stages of C. oleifera.

\begin{tabular}{|c|c|c|}
\hline Month & Stage & Characteristics \\
\hline Mid-April to early June & Slow growth stage & Fruit size and weight increased slowly, the ovule started to germinate \\
\hline Early June to late July & Rapid growth stage & Fruit size and weight increased rapidly, ovule developed into a complete seed \\
\hline Early August to early October & Oil conversion stage & $\begin{array}{l}\text { Weights of seeds and kernels in fruit increased rapidly, the accumulated } \\
\text { starch in the seed was gradually converted into oil, the oil content increased }\end{array}$ \\
\hline Early October to before harvest & Maturation stage & Fruit size was stable, the oil accumulation peaked \\
\hline
\end{tabular}

Table 3. Characteristics of new shoots, leaves, and fruit.

\begin{tabular}{|c|c|c|c|c|c|}
\hline Organ & First leaf & Third leaf & Fifth leaf & Fruit & New shoot \\
\hline Width (cm) & $2.78 \pm 0.06$ & $2.91 \pm 0.05$ & $3.03 \pm 0.04$ & l & 1 \\
\hline Length (cm) & $4.62 \pm 0.03$ & $4.81 \pm 0.05$ & $5.03 \pm 0.06$ & / & $11.23 \pm 0.23$ \\
\hline Vertical diameter $(\mathrm{mm})$ & 1 & / & 1 & $13.08 \pm 0.21$ & / \\
\hline Transverse diameter (mm) & l & l & l & $11.50 \pm 0.11$ & / \\
\hline
\end{tabular}

Data are presented as mean \pm SD.

photosynthetic capacity as well as the allocation of photoassimilates to flower buds and fruit in different $C$. oleifera leaves, which has an important role in flower bud formation and fruit development and affects the current and following year fruit yields, have not been fully examined. During this study, we conducted ${ }^{13} \mathrm{C}$-labeling experiments involving $C$. oleifera to study the dynamics of allocation of assimilates from different source leaves to buds and fruits during different fruit growth periods and the role of leaves in different positions supplying assimilates to the buds and fruits. The specific objectives of this study were to examine: 1) which leaf provides more assimilates to flower buds that contribute to flower bud differentiation; 2) which leaf is the most important for feeding fruit that bears on the first node of last year's bearing shoot; and 3) which period during fruit growth and development is the most competitive for assimilates between flower bud differentiation and fruit growth. Our work may clarify the mechanism of alternate bearing of $C$. oleifera and may provide a basis for the cultivation and renewal of fruitbearing branches.

\section{Material and Methods}

Experimental location and plant materials. A field experiment was conducted at the $\mathrm{Na}$ tional Oil-tea Camellia Engineering and Technology Research Center, Changsha, Hunan Province, China (altitude, 80-100 m; lat. $28^{\circ} 14^{\prime} 24^{\prime \prime} \mathrm{N}$; long. $113^{\circ} 10^{\prime} 12^{\prime \prime} \mathrm{E}$ ), with an annual average temperature of $16.8{ }^{\circ} \mathrm{C}$ and annual rainfall of $1455.5 \mathrm{~mm}$. The experimental site was suitable for planting $C$. oleifera, and it was also the main growing area for $C$. oleifera. Trees were grown in north-to-south rows spaced $2 \mathrm{~m} \times 3 \mathrm{~m}$ that were $2 \mathrm{~m}$ high.
Three 10-year-old trees of clonal cultivar Xiang lin 27 were used in this experiment. The trees were grown under the same site conditions, with strong growth vigor and no disease or pest problems (Fig. 1). The different developmental stages of flower bud differentiation and fruit growth of $C$. oleifera are shown in Table 1 (Wang et al., 2011; Yuan et al., 2011) and Table 2 (Chen et al., 2006), respectively. There were $\approx 1200$ new shoots in each tree, and the numbers of new shoots were similar among three plants. We selected 150 new shoots of the three trees on 15 May 2016, during the slow stage of fruit growth. All the new shoots had stopped growing and the terminal buds had formed. Furthermore, the selected new shoots had the same growth vigor and did not have secondary growth in the fall, with five leaves and only one fruit that bore on the first node of last year's bearing shoot. The flower buds and leaf buds were on the new shoot, which grew in the current year. The characteristics of new shoot, leaf, and fruit are shown in Table 3.

${ }^{13} \mathrm{C}$ labeling. Of the 150 new shoots, 60 were used for ${ }^{13} \mathrm{C}$-isotope labeling to calculate the allocation of the ${ }^{13} \mathrm{C}$-labeled photoassimilates from different source leaves (first, third, and fifth leaves) (Fig. 2) to the different sinks during the different fruit growth stages. Of the 60 new shoots, 20 each were used for labeling the first, third, and fifth leaves, respectively; four shoots of each type of labeled leaf were chosen at each sampling time, including the slow growth $(4 \mathrm{~h}$ and $10 \mathrm{~d}$ after ${ }^{13} \mathrm{C}$ labeling), rapid growth (63 $\mathrm{d}$ after ${ }^{13}$ $\mathrm{C}$ labeling), oil conversion (129 d after ${ }^{13} \mathrm{C}$ labeling), and maturation (159 d after ${ }^{13} \mathrm{C}$ labeling). Current photoassimilates were labeled with ${ }^{13} \mathrm{CO}_{2}$ using the method described by Shi (2015) with some modification, and the ${ }^{13} \mathrm{C}$-labeling experiments were conducted at 9:00 AM on 16 May 2016, during the slow stage of fruit growth. For labeling, each leaf was enclosed in a single transparent polyethylene bag $(\approx 1 \mathrm{~L}$ in volume $)$. The air was pumped out of the bag. Then, the bag was injected with air without $\mathrm{CO}_{2}$ and $\mathrm{H}_{2} \mathrm{O}$, which were absorbed by sodalime (main components, $\mathrm{CaO}$ and $\mathrm{NaOH}$ ). Finally, $50 \mathrm{~mL}{ }^{13} \mathrm{CO}_{2}\left(99 \%\right.$ atom ${ }^{13} \mathrm{C} ; 99 \%$ concentration of ${ }^{13} \mathrm{CO}_{2}$; Shanghai Research Institute of Chemical Industry, Shanghai, China) was injected into the bag using a syringe. We shook each labeled leaf every $30 \mathrm{~min}$ to evenly distribute the ${ }^{13} \mathrm{CO}_{2}$ in the bag. After maintaining photosynthesis for 4 $\mathrm{h}, \mathrm{KOH}$ solution was used to absorb the residual ${ }^{13} \mathrm{CO}_{2}$; then, all the plastic bags were removed. Labeled leaves and the other organs on the same new shoots, including the shoots, unlabeled leaves, flower buds, leaf buds, and fruit, were also sampled during the main fruit developmental stage. Samples were separately dried at $105^{\circ} \mathrm{C}$ to a constant dry weight and ground to a homogeneous powder using a sample mill (A10; IKA, Staufen, Germany). The dry weight of each tissue was sufficient for the quantification analysis of ${ }^{13} \mathrm{C}$. The abundance of ${ }^{13} \mathrm{C}$ was determined using a mass spectrometer. According to the requirements of the equipment, $2 \mathrm{mg}$ was the minimum required for sample determination. During this experiment, $5 \mathrm{mg}$ of each sample was weighed.

Measurement and analysis of ${ }^{13} \mathrm{C}$. The abundance of ${ }^{13} \mathrm{C}$ was determined using a mass spectrometer (IsoPrime 100; IsoPrime Ltd., Manchester, UK), and the allocation of ${ }^{13} \mathrm{C}$ was calculated relative to the Vienna-Pee Dee Belemnite reference standard for $\delta^{13} \mathrm{C}$ : 


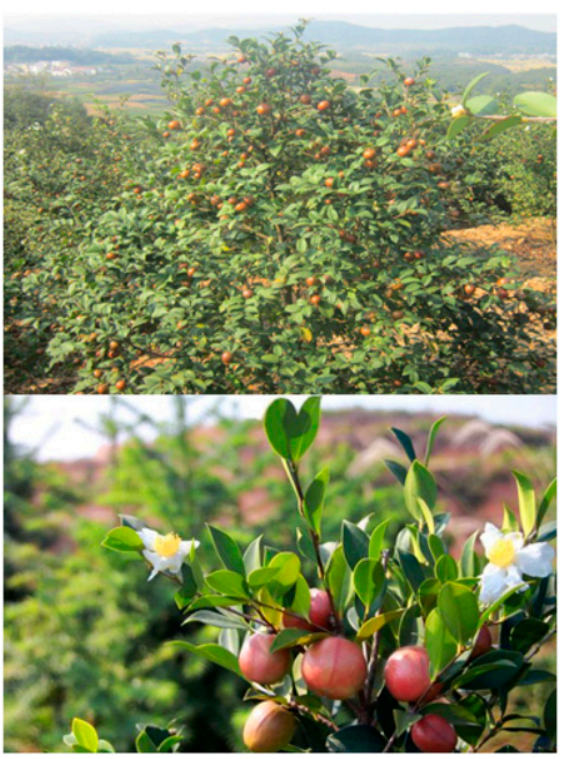

Fig. 1. Image of Camellia oleifera.

$$
\begin{aligned}
\delta^{13} \mathrm{C}(\% \mathrm{oo})= & \left(\mathrm{R}_{\mathrm{s}} / \mathrm{R}_{\mathrm{r}}-1\right) \times 1000, \\
{ }^{13} \mathrm{C}(\text { atom } \%)= & \left(\delta^{13} \mathrm{C}+1000\right) \\
& \times \mathrm{R}_{\mathrm{r}} /\left[\left(\delta^{13} \mathrm{C}+1000\right)\right. \\
& \left.\times \mathrm{R}_{\mathrm{r}}+1000\right] \times 1000,
\end{aligned}
$$

$\mathrm{Ci}(\mathrm{g})=$ amount $=$ of dry matter $(\mathrm{g}) \times \mathrm{C} \%$

$$
\begin{aligned}
{ }^{13} \mathrm{C} & (\mathrm{mg}) \\
= & \mathrm{Ci} \times\left[{ }^{13} \mathrm{C}(\text { atom } \%) \text { of } \mathrm{R}_{\mathrm{s}}\right. \\
& \left.-{ }^{13} \mathrm{C}(\text { atom } \%) \text { of } \mathrm{R}_{\mathrm{r}}\right] \\
& \times 1000,
\end{aligned}
$$

where $\mathrm{R}$ represents the standard ratio of the carbon isotope $\left({ }^{12} \mathrm{C} /{ }^{13} \mathrm{C}, 0.0112372\right)$ and the subscripts $\mathrm{s}$ and $\mathrm{r}$ represent the sample and reference, respectively. ${ }^{13} \mathrm{C}$ (atom\%) represents the ratio of ${ }^{13} \mathrm{C}$ atoms in the total carbon atoms. $\mathrm{Ci}(\mathrm{g})$ and ${ }^{13} \mathrm{Ci}(\mathrm{mg})$ represent the total carbon content and amount of ${ }^{13} \mathrm{C}$ in the plant organ, respectively.

Determination of dry matter accumulation. Of the 150 new shoots, the 20 new shoots were used to calculate the dry matter accumulation in each organ of the shoot at different fruit developmental stages, including the following: shoot; first, third, and fifth leaves; first and third flower buds; first, third, fourth, and fifth leaf buds and fruit; and four new shoots for each stage. Samples were separately dried at $105^{\circ} \mathrm{C}$ to a constant dry weight and weighted with a ten-thousandth balance.

Determination of photosynthetic characteristics and leaf area. Of the 150 new shoots, 40 were used for measurements of photosynthetic characteristics and leaf area during different fruit developmental periods. Photosynthetic characteristics mainly included the chlorophyll (Chl) concentrations, net photosynthetic rate $\left(\mathrm{P}_{\mathrm{n}}\right)$, and $\mathrm{Chl}$ fluorescence.

Of the 40 new shoots, 20 were selected for measurements of the $\mathrm{Chl}$ concentrations and four new shoots for each stage. Counting downward from the top, the first, third, and fifth healthy leaves on the four new shoots, which were at the same developmental stage on the sunny side of the upper canopy, were collected. The different leaf samples were stored separately.

The chlorophyll concentrations ( $\mathrm{Chl}$ a, $\mathrm{Chl} \mathrm{b}$, and $\mathrm{Chl} \mathrm{a}+\mathrm{b}$ ) were determined by a spectrophotometer (Shimadzu ultraviolet2550; Kyoto, Japan). A 0.5-g fresh leaf sample was ground in liquid nitrogen and then diluted with $80 \%$ acetone. The Chl concentrations were detected at 645 and $663 \mathrm{~nm}$ and calculated using the following three formulas:

$$
\begin{aligned}
& \text { Chl a }[\mathrm{mg} / \mathrm{g} \text { fresh weight }(\mathrm{FW})] \\
& =(12.7 \times \text { OD663 }-2.69 \times \text { OD645 }) \\
& \times \mathrm{V} /(1000 \times \mathrm{W}) \\
& \mathrm{Chl} b(\mathrm{mg} / \mathrm{g} \mathrm{FW}) \\
& =(22.90 \times \text { OD } 645-4.68 \times \text { OD663 }) \\
& \times \mathrm{V} /(1000 \times \mathrm{W}) \\
& \mathrm{Chla}+\mathrm{b}(\mathrm{mg} / \mathrm{gFW}) \\
& =(8.02 \times \text { OD663 }+20.21 \times \text { OD645 }) \\
& \times \mathrm{V} /(1000 \times \mathrm{W}) \\
& \operatorname{Chl}(\mathrm{a} / \mathrm{b})=\mathrm{Chla} / \mathrm{Chl} \mathrm{b},
\end{aligned}
$$

where $\mathrm{Chl}$ a $(\mathrm{mg} / \mathrm{g} \mathrm{FW})$ indicates the concentration of $\mathrm{Chl} \mathrm{a}, \mathrm{Chl} \mathrm{b}(\mathrm{mg} / \mathrm{g} \mathrm{FW})$ indicates the concentration of $\mathrm{Chl} \mathrm{b}, \mathrm{Chl} \mathrm{a}+\mathrm{b}$ $(\mathrm{mg} / \mathrm{g} \mathrm{FW})$ indicates the concentration of total $\mathrm{Chl}, \mathrm{Chl}(\mathrm{a} / \mathrm{b})$ indicates the ratio of concentrations of Chl a and b, OD645 and OD663 represent the optical density at wavelengths of 645 and $663 \mathrm{~nm}$, respectively, $\mathrm{V}(\mathrm{mL})$ indicates the volume of $80 \%$ acetone, and $\mathrm{W}(\mathrm{g})$ indicates the FW of the samples.

Of the 40 new shoots, the remaining 20 new shoots were used to determine the $\mathrm{P}_{\mathrm{n}}, \mathrm{Chl}$ fluorescence and leaf area, and four new shoots for each stage. Counting downward from the top, the first, third, and fifth healthy mature leaves on the four new shoots were collected to determine the $\mathrm{P}_{\mathrm{n}}$ and Chl fluorescence. The $\mathrm{P}_{\mathrm{n}}$ and Chl fluorescence, including the maximal photochemical efficiency (Fv/ Fm) of photosystem II (PSII), electron transportation rate (ETR) of PSII, and actual photochemical efficiency (ФPSII), were estimated between 9:00 and 11:00 AM on a clear, sunny day at different fruit growth stages with a portable photosynthesis system (LI-6400; LI-COR Inc., Lincoln, NE). After being fully light-activated, leaves were illuminated at $1200 \mu \mathrm{mol} \cdot \mathrm{m}^{-2} \cdot \mathrm{s}^{-1}$ photosynthetically active radiation $(P A R)$ produced by the Li-6400 photosynthesis system to determine $P_{n}$. When measuring the Chl fluorescence parameters, leaf samples were previously adapted to darkness for $30 \mathrm{~min}$. The ETR was directly measured with the Li-6400 photosynthesis system according to the following principle:

$$
\begin{aligned}
\text { ETR }= & \text { PPFD } \times \text { ФPSII } \\
& \times 0.84 \times 0.50,
\end{aligned}
$$

$\Phi P S I I=\left(\mathrm{Fm}^{\prime}-\mathrm{Fs}\right) / \mathrm{Fm}^{\prime}$,

where $P P F D$ indicates the photosynthetic photon flux density obtained by manually setting the light source, $P P F D=1200$ $\mu \mathrm{mol} \cdot \mathrm{m}^{-2} \cdot \mathrm{s}^{-1}$, PPSII indicates the actual photochemical efficiency, $\mathrm{Fm}^{\prime}$ indicates the maximal fluorescence intensity of the light, and Fs indicates the steady-state fluorescence. A portable leaf area meter (CI-202; CID Inc., Vancouver, WA) was used to measure the leaf area.

Proportion of flower buds at each leaf node. Of the 150 new shoots, the remaining 30 new shoots were used to calculate the proportion of flower buds at each leaf node. The proportion of flower buds refers to the number of buds that flower out of the total number of buds on each new shoot. The numbers of leaf and flower buds at each leaf node on each new shoot chosen in the experiment were counted on 1 Sept. 2016, during the maturation stage of stamens and pistils, when the selected new shoots still had five leaves and only one fruit on the first node of last year's bearing shoot. Then, the proportion of flower buds at different leaf nodes was calculated.

Statistical analysis. All data were tested using a one-way analysis of variance (SPSS 18.0; SPSS Inc., Chicago, IL). A multiple comparison of means was conducted using Duncan's test at $\alpha \leq 0.05$. For all statistical analyses, $P \leq 0.05$ was deemed significant and differences at $P \geq 0.05$ were considered nonsignificant.

\section{Results}

Leaf area and photosynthetic characteristics of first, third, and fifth leaves during different fruit growth stages. During the first two periods of fruit development, the leaf area of each node increased significantly, and the first leaf had the fastest increase (Fig. 3A). The leaf area of the first, third, and fifth leaves remained stable during the oil conversion stage and maturation

Fig. 2. Schematic diagram of the ${ }^{13} \mathrm{C}$ addition during the experiment. (A) Labeled first leaf. (B) Labeled third leaf. (C) Labeled fifth leaf.

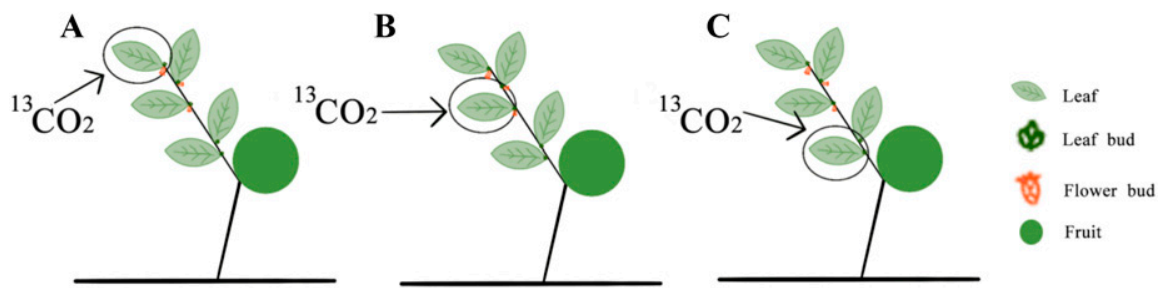


$\square 1^{\text {st }}$ Leaf $\square 3^{\text {rd }}$ Leaf $\quad \square 5^{\text {th }}$ Leaf

A

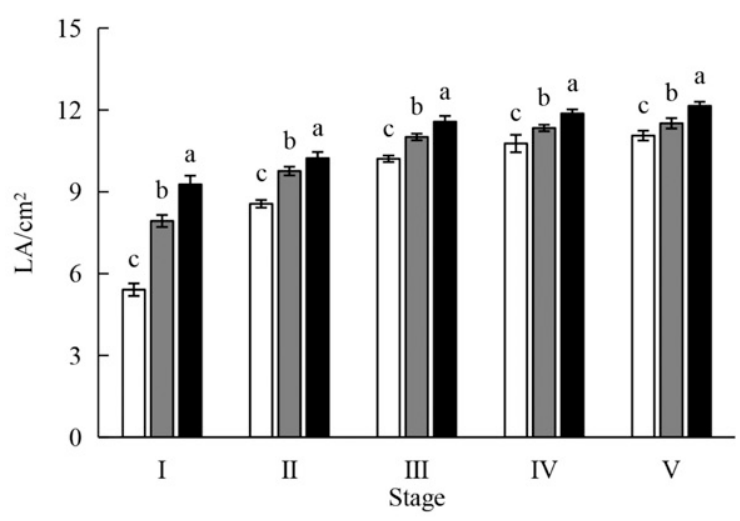

C

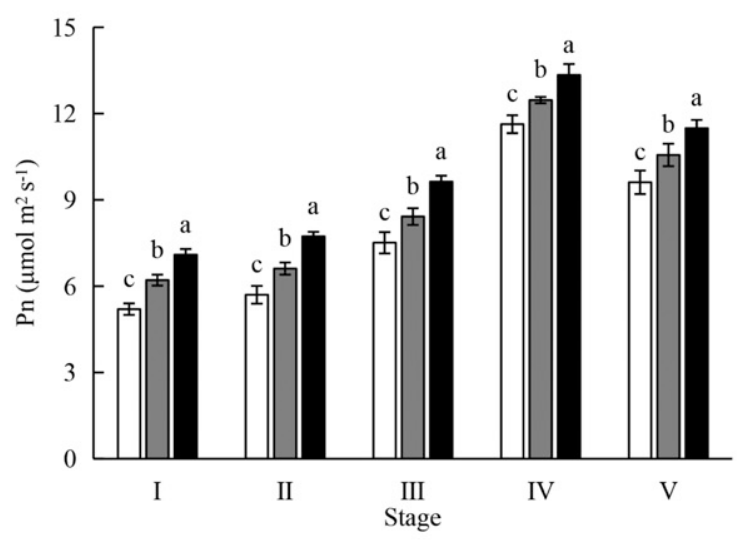

E

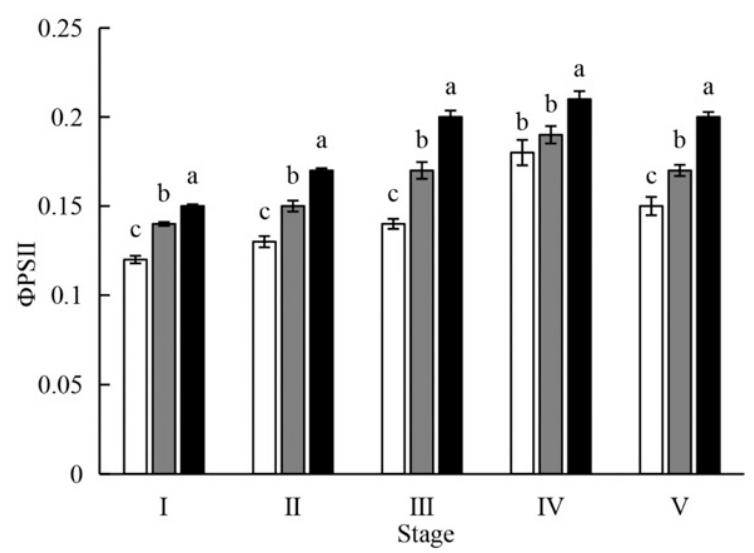

B

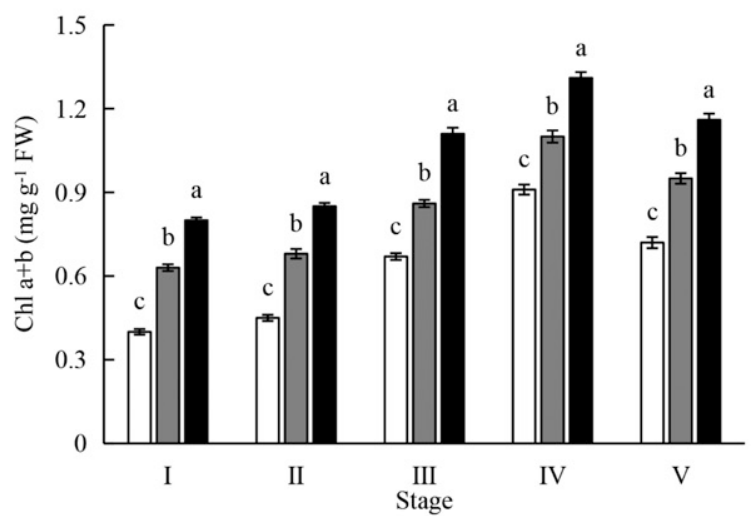

D

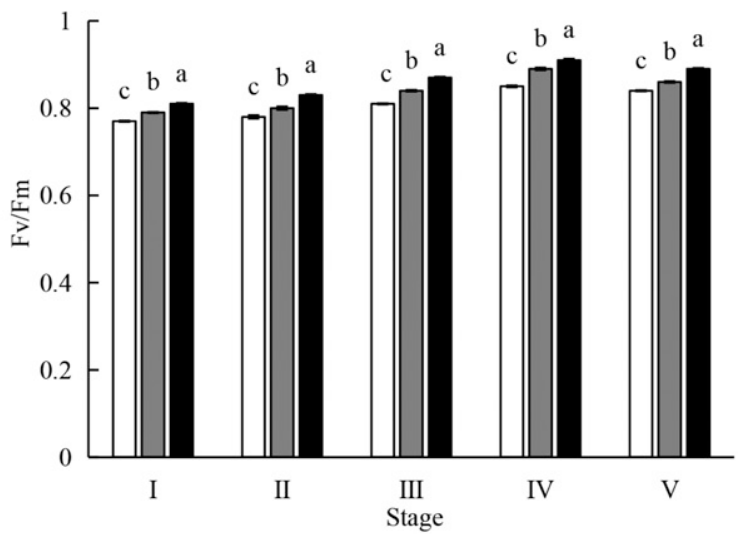

F

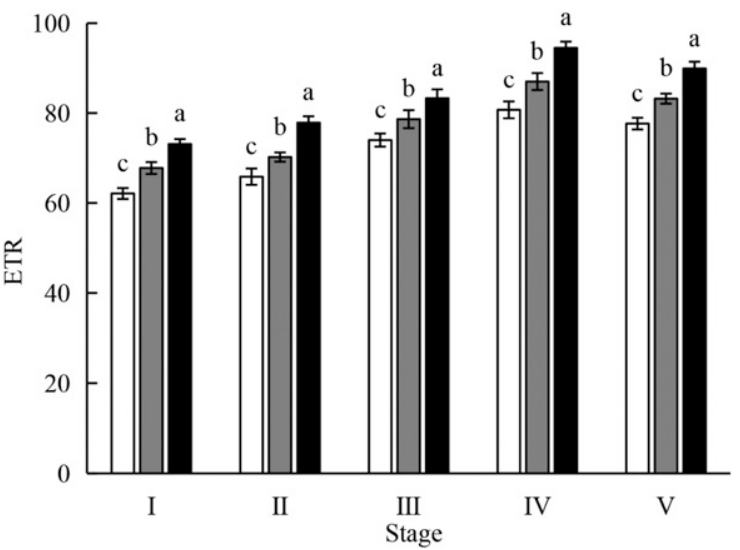

Fig. 3. Leaf area and photosynthetic characteristics of the first, third, and fifth leaves at the different fruit growth stages: $\mathrm{I}$, slow growth stage $\left(4 \mathrm{~h}\right.$ after ${ }^{13} \mathrm{C}$ labeling); II, slow growth stage ( $10 \mathrm{~d}$ after ${ }^{13} \mathrm{C}$ labeling); III, rapid growth stage $\left(63 \mathrm{~d}\right.$ after ${ }^{13} \mathrm{C}$ labeling); IV, oil conversion stage $\left(129 \mathrm{~d}\right.$ after ${ }^{13} \mathrm{C}$ labeling); $\mathrm{V}$, maturation stage (159 d after ${ }^{13} \mathrm{C}$ labeling). (A) Leaf area. (B) Chlorophyll (Chl) a $+\mathrm{b}$ content. (C) Net photosynthetic rate $\left(\mathrm{P}_{\mathrm{n}}\right)$. (D) Maximal photochemical efficiency $(\mathrm{Fv} / \mathrm{Fm})$. (E) $\Phi$ photosystem II (PSII). (F) Electron transportation rate (ETR). Data are presented as means \pm SD. Bars with different letters differ statistically according to Duncan's test at $\alpha \leq 0.05$.

stage. The Chl a+b, $\mathrm{P}_{\mathrm{n}}, \mathrm{Fv} / \mathrm{Fm}$, ФPSII, and ETR increased with the leaf position (Fig. 3B-F), and there were significant differences $(P \leq$ 0.05 ) in the leaf area and photosynthetic characteristics among leaves in different positions.
In addition, photosynthetic characteristics increased over time as follows: oil conversion stage $>$ maturation stage $>$ rapid growth stage $>$ early growth stage. Furthermore, the $\mathrm{Chl} \mathrm{a}+\mathrm{b}$, $\mathrm{P}_{\mathrm{n}}, \mathrm{Fv} / \mathrm{Fm}$, ФPSII, and ETR values of the fifth leaves during the oil conversion period were 1.44-, 1.14-, 1.07-, 1.17-, and 1.17-times that of those recorded for the first leaves.

Dry matter accumulation in each organ of the new shoot during different fruit growth 

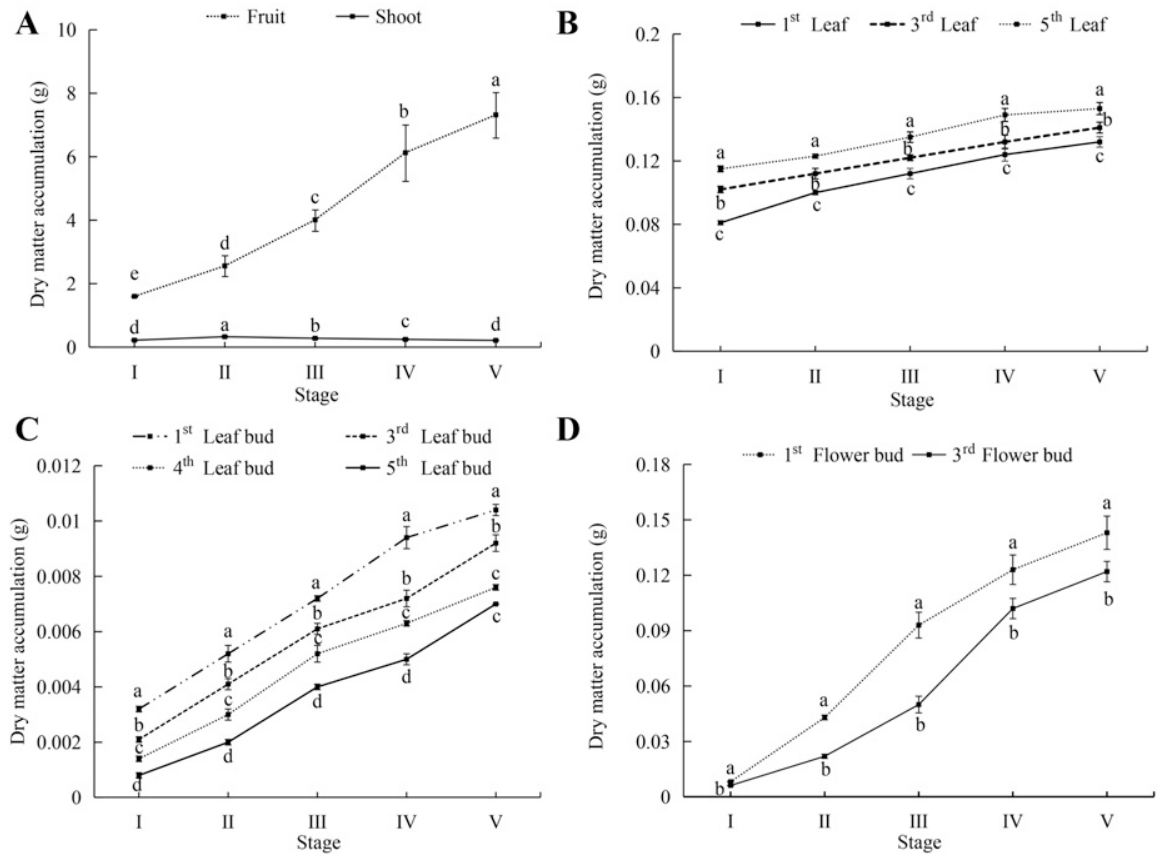

D

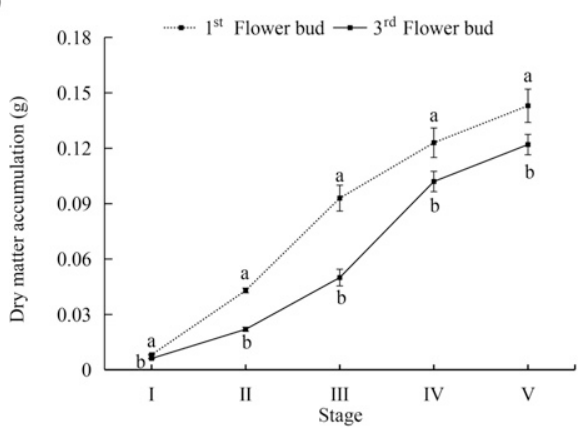

Fig. 4. Dry matter accumulation (g) in each organ of the new shoot at different fruit growth stages: I, slow growth stage ( $4 \mathrm{~h}$ after ${ }^{13} \mathrm{C}$ labeling); II, slow growth stage $\left(10 \mathrm{~d}\right.$ after ${ }^{13} \mathrm{C}$ labeling); III, Rapid growth stage (63 d after ${ }^{13} \mathrm{C}$ labeling); IV, oil conversion stage (129 d after ${ }^{13} \mathrm{C}$ labeling); $\mathrm{V}$, maturation stage (159 d after ${ }^{13} \mathrm{C}$ labeling). (A) Fruit and shoot. (B) First, third, and fifth leaves. (C) First, third, fourth, and fifth leaf buds. (D) First and third flower buds. Data are presented as mean \pm SD. Bars with different letters differ statistically according to Duncan's test at $\alpha \leq 0.05$.
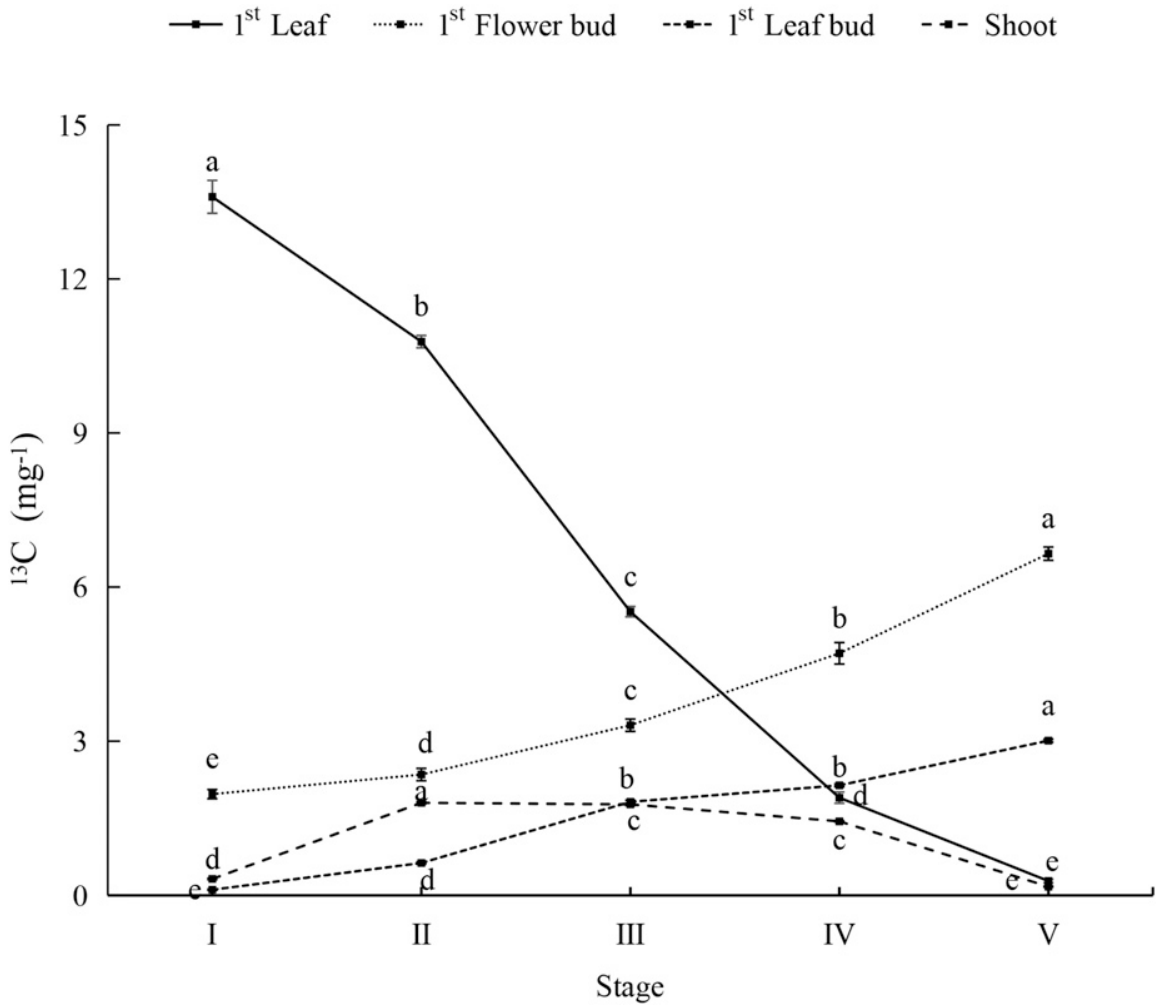

Fig. 5. Accumulation and allocation of ${ }^{13} \mathrm{C}$ assimilates $\left(\mathrm{mg}^{-1}\right)$ in the first leaf at different fruit growth stages; I, slow growth stage ( $4 \mathrm{~h}$ after ${ }^{13} \mathrm{C}$ labeling); II, slow growth stage $\left(10 \mathrm{~d}\right.$ after ${ }^{13} \mathrm{C}$ labeling); III, rapid growth stage (63 d after ${ }^{13} \mathrm{C}$ labeling); IV, oil conversion stage (129 d after ${ }^{13} \mathrm{C}$ labeling); $\mathrm{V}$, maturation stage ( $159 \mathrm{~d}$ after ${ }^{13} \mathrm{C}$ labeling). Data are presented as mean \pm SD. Bars with different letters differ statistically according to Duncan's test at $\alpha \leq 0.05$. stages. Dry matter accumulations in the fruit, leaf, flower bud, and leaf bud increased with fruit development (Fig. 4). However, dry matter accumulations in the shoot at different fruit development stages were as follows: slow growth stage $\left(10 \mathrm{~d}\right.$ after ${ }^{13} \mathrm{C}$ labeling; $0.382 \mathrm{~g})>$ rapid growth stage $(0.279 \mathrm{~g})>$ oil conversion stage $(0.244 \mathrm{~g})>$ slow growth stage $\left(4 \mathrm{~h}\right.$ after ${ }^{13} \mathrm{C}$ labeling; $\left.0.219 \mathrm{~g}\right)>$ maturation stage $(0.213 \mathrm{~g})$. In addition, there were significant differences in dry matter accumulations in the leaf, flower bud, and leaf bud at different leaf nodes during each fruit development stage, and the dry matter accumulations in the leaf, flower bud, and leaf bud were as follows: fifth leaf $>$ third leaf $>$ first leaf, first flower bud $>$ third flower bud, first leaf bud $>$ third leaf bud $>$ fourth leaf bud $>$ fifth leaf bud.

Accumulation and allocation of ${ }^{13} \mathrm{C}$ assimilates in the first, third, and fifth leaves during different fruit growth stages. The total amounts of ${ }^{13} \mathrm{C}$ assimilates in the first, third, and fifth leaves all decreased gradually with fruit development as follow: slow growth stage $\left(4 \mathrm{~h}\right.$ after ${ }^{13} \mathrm{C}$ labeling) $>$ slow growth stage $\left(10 \mathrm{~d}\right.$ after ${ }^{13} \mathrm{C}$ labeling) $>$ rapid growth stage $>$ oil conversion stage $>$ maturation stage (Figs. 5-7).

The allocation of ${ }^{13} \mathrm{C}$ assimilates from the first leaf to the different organs were determined at different fruit growth stages (Fig. 5). The ${ }^{13} \mathrm{C}$ assimilates reserve decreased in the first leaf, while the amount of ${ }^{13} \mathrm{C}$ sent to the first flower bud and first leaf bud continued to increase over time, and ${ }^{13} \mathrm{C}$ assimilates levels in first flower bud were always greater than that of the first leaf bud. At maturation stage, most ${ }^{13} \mathrm{C}$ assimilates were allocated to the first flower bud $(65.47 \%)$ and first leaf bud (30.04\%), while there were little ${ }^{13} \mathrm{C}$ assimilates reserved in the leaf $(2.79 \%)$ and shoot $(1.70 \%)$. In addition, there were no ${ }^{13} \mathrm{C}$ assimilates allocated to the other organs on the same shoot.

The allocation of ${ }^{13} \mathrm{C}$ assimilates from the third leaf to each organ changed over time (Fig. 6). The residual ${ }^{13} \mathrm{C}$ in the original labeled leaf decreased gradually; however, levels in the third flower and third leaf buds showed the opposite tendency. From the period of rapid growth, ${ }^{13} \mathrm{C}$ assimilates were allocated to the fourth leaf bud and fruit (peel and kernel). Furthermore, during the oil conversion stage, maximum increases in the ${ }^{13} \mathrm{C}$ accumulation of up to 4.13 and $2.72 \mathrm{mg}$ occurred in the third flower bud and third leaf bud; increases also occurred in the fruit kernel $(1.82 \mathrm{mg})$. During the maturation stage, most ${ }^{13} \mathrm{C}$ assimilates were allocated to the third flower bud $(33.85 \%)$, third leaf bud $(23.14 \%)$, and fruit $(29.74 \%)$; however, there were few ${ }^{13} \mathrm{C}$ assimilates reserved in the leaf $(3.54 \%)$ and shoot $(1.00 \%)$. However, no ${ }^{13} \mathrm{C}$ assimilates were found in other organs on the same shoot.

The ${ }^{13} \mathrm{C}$ assimilates that were assimilated by the fifth leaf were already detected in the fifth leaf bud at a low level $4 \mathrm{~h}$ after labeling (Fig. 7), whereas the ${ }^{13} \mathrm{C}$ accumulation of $0.85 \mathrm{mg}$ in fruit $(0.23 \mathrm{mg}$ in peel and $0.62 \mathrm{mg}$ 

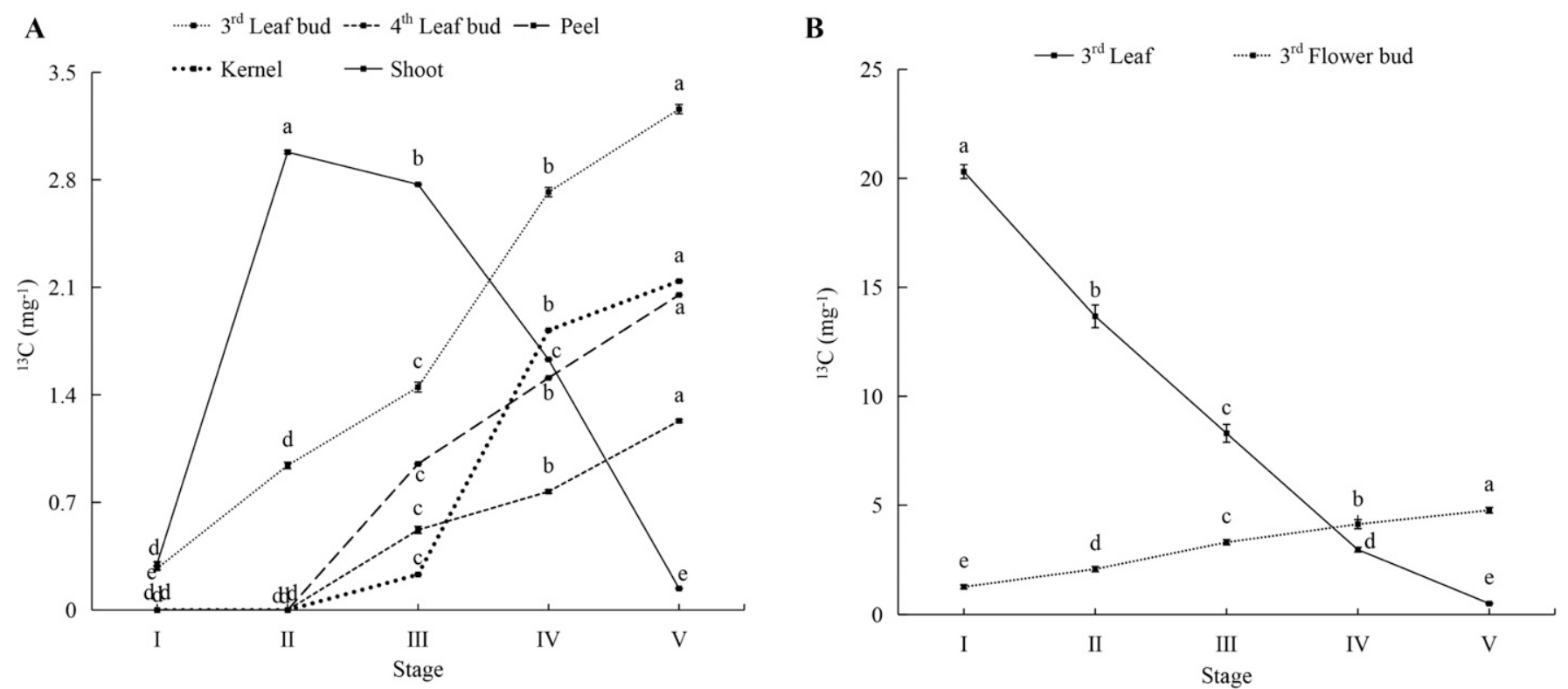

Fig. 6. Accumulation and allocation of ${ }^{13} \mathrm{C}$ assimilates $\left(\mathrm{mg}^{-1}\right)$ in the third leaf at different fruit growth stages: I, slow growth stage ( $4 \mathrm{~h}$ after ${ }^{13} \mathrm{C}$ labeling); II, slow growth stage ( $10 \mathrm{~d}$ after ${ }^{13} \mathrm{C}$ labeling); III, rapid growth stage ( $63 \mathrm{~d}$ after ${ }^{13} \mathrm{C}$ labeling); IV, oil conversion stage $\left(129 \mathrm{~d}\right.$ after ${ }^{13} \mathrm{C}$ labeling); V, maturation stage (159 d after ${ }^{13} \mathrm{C}$ labeling). (A) Third and fourth leaf buds, peel, kernel, and shoot. (B) Third leaf and third flower bud. Data are presented as means \pm SD. Bars with different letters differ statistically according to Duncan's test at $\alpha \leq 0.05$.
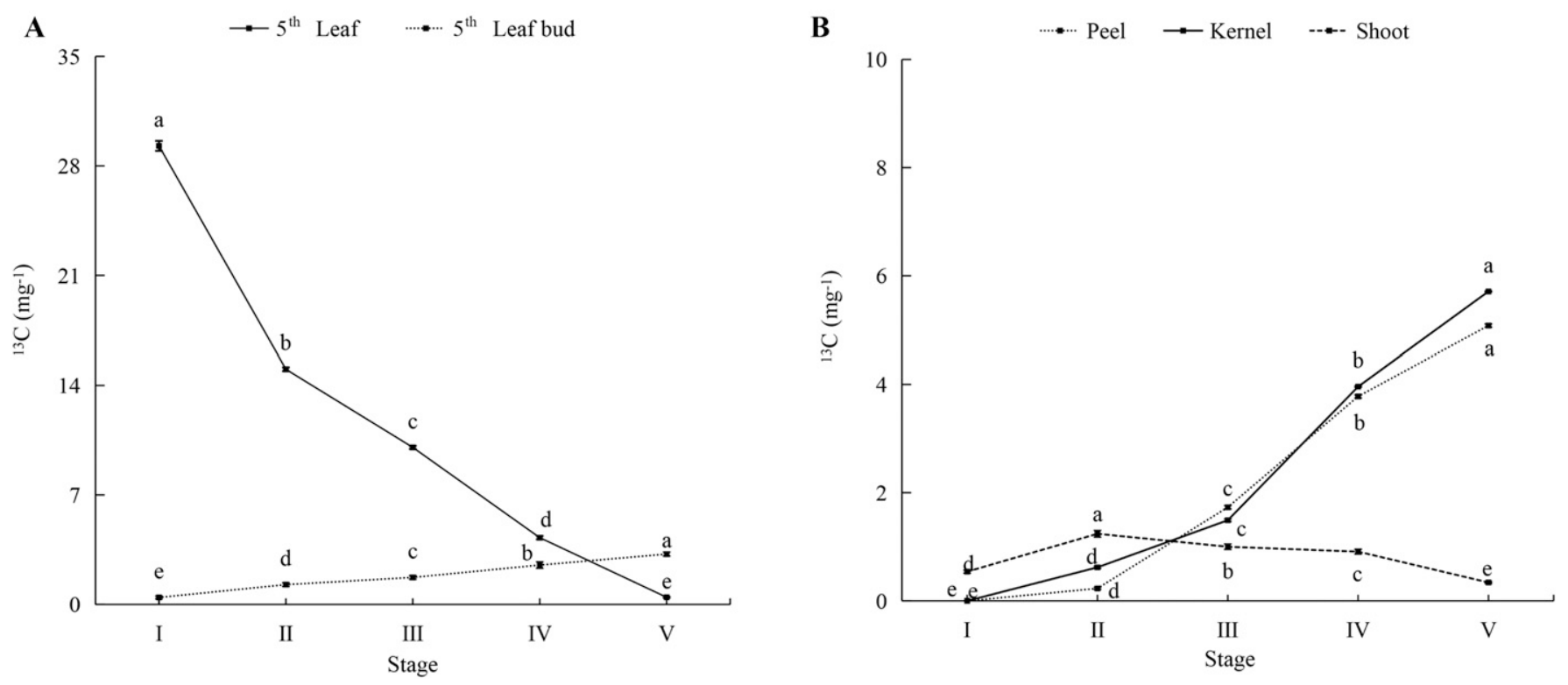

Fig. 7. Accumulation and allocation of ${ }^{13} \mathrm{C}$ assimilates $\left(\mathrm{mg}^{-1}\right)$ in the fifth leaf at different fruit growth stages: I, slow growth stage $\left(4 \mathrm{~h}\right.$ after ${ }^{13} \mathrm{C}$ labeling); II, slow growth stage (10 d after ${ }^{13} \mathrm{C}$ labeling); III, rapid growth stage ( $63 \mathrm{~d}$ after ${ }^{13} \mathrm{C}$ labeling); IV, oil conversion stage $\left(129 \mathrm{~d}\right.$ after ${ }^{13} \mathrm{C}$ labeling); V, maturation stage (159 d after ${ }^{13} \mathrm{C}$ labeling). (A) Fifth leaf and fifth leaf bud. (B) Peel, kernel, and shoot. Data are presented as means \pm SD. Bars with different letters differ statistically according to Duncan's test at $\alpha \leq 0.05$.

in kernel) was first observed $10 \mathrm{~d}$ after labeling. ${ }^{13} \mathrm{C}$ assimilates allocated to the fifth leaf bud, fruit peel, and kernel gradually accumulated over time. Furthermore, the increased levels of ${ }^{13} \mathrm{C}$ assimilates in fruit (peel and kernel) were always higher than those in the fifth leaf bud from the rapid growth stage. At the maturation stage, most of the ${ }^{13} \mathrm{C}$ assimilates had accumulated in the fruit $(72.86 \%)$; however, there were few ${ }^{13} \mathrm{C}$ assimilates reserved in the leaf (3.11\%) and shoot (2.29\%). In addition, ${ }^{13} \mathrm{C}$ assimilates did not exist in other adjacent organs on the same shoot.
Proportion of flower buds at each leaf node. Figure 8 shows the buds at the first and second leaf nodes on each shoot simultaneously differentiated into leaf and flower buds. The majority of buds at the third leaf node also differentiated into flower and leaf buds. However, the buds at the fourth and fifth nodes only formed leaf buds. The proportions of flower buds at each leaf node were as follows: first leaf node $(71.00 \%)>$ second leaf node $(65.00 \%)>$ third leaf node $(52.33 \%)>$ fourth leaf node (fifth leaf node) $(0.00 \%)$.

\section{Discussion}

Effects of leaf position and fruit growth period on photosynthetic characteristics. Photosynthesis is the basis of plant growth and development, and it has an important role in fruit productivity. During the early fruit growth stage, $C$. oleifera leaves at the upper node position (first leaf) do not completely expand to twothirds the size of a whole leaf, which is a source that can transport photoassimilates to the sink for $\mathrm{P}_{\mathrm{n}}>0 \mu \mathrm{mol} \cdot \mathrm{m}^{-2} \cdot \mathrm{s}^{-1}$ and $\mathrm{P}_{\mathrm{n}}$ increases, along with the Chl concentration, even though the 


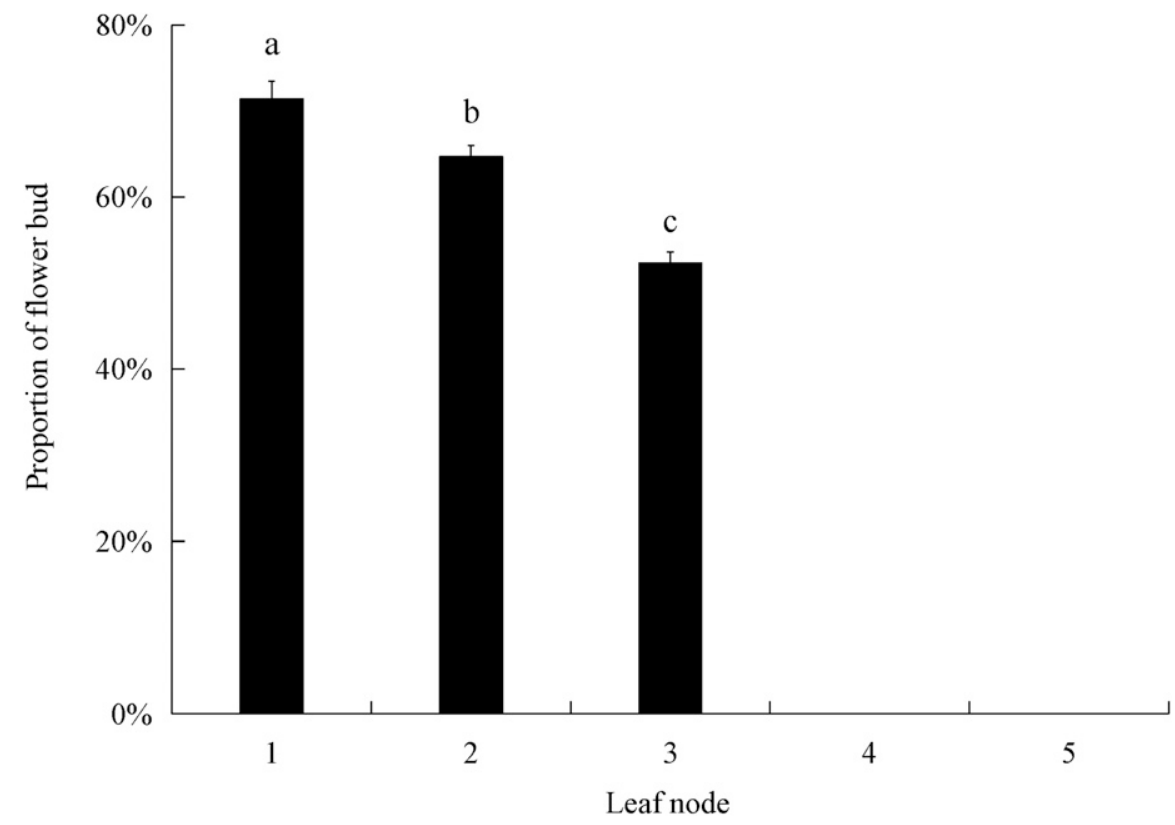

Fig. 8. Proportion of flower buds at each leaf node. Data are presented as means \pm SD. Bars with different letters differ statistically according to Duncan's test at $\alpha \leq 0.05$.

leaves are not completely expanded (Takai et al., 2010). Furthermore, the leaf area of first leaf increased fastest among the three leaves, which indicated that the first leaf had the most active growth. Each leaf might stop growing during the oil conversion stage. During this study, the first, third, and fifth leaves were not in senescence during the whole fruit growth stages based on the high $\mathrm{P}_{\mathrm{n}}$ values of the leaves. In addition, the significant differences in photosynthesis levels among $C$. oleifera leaves are related to their different positions on the shoot (Kositsup et al., 2010). Each leaf position correlated with leaf age, resulting in differences in the physiological metabolic processes (Wang et al., 2014a). During this study, the Chl concentration, $\mathrm{P}_{\mathrm{n}}$, and all the fluorescence parameters in the fifth leaf were always greater than those of the first and third leaves because the leaf at the fifth position was older than those at the first and third positions (Wu et al., 2016).

The photosynthesis level increases in leaves as the plant develops. In C. oleifera leaves, all photosynthetic characteristics reached maximum values during the oil conversion stage. The oil conversion period is accompanied by active metabolic physiology (Zhou et al., 2013), with an ever-growing demand for assimilates resulting in high levels of photosynthesis-related characteristics (He, 2010), which contribute to an increased level of chemical energy in the form of carbohydrates and other organic compounds for oil formation (Lestari et al., 2011). This may be assisted by the suitable climate conditions during this period between August and September, especially the high light intensity, which promotes assimilate transportation, partitioning, and accumulation (Wen et al., 2018b; Yuan et al., 2015). Furthermore, enough dry matter accumula- tion would benefit the development of sinks, such as the fruit, flower bud, and leaf bud. Furthermore, during the oil conversion stage, there is no excess Chl concentration to fuel the high photosynthesis rate; therefore, the Chl concentration may reflect the $P_{n}$ (Wang et al., 2014b).

Effects of source-sink relationships on ${ }^{13}$ C-labeled photoassimilate allocation. Regardless of the node position, the total amount of ${ }^{13} \mathrm{C}$-labeled photoassimilates supplied by each labeled leaf decreased gradually over time while increasing in buds and fruit. The ${ }^{13}$ C-labeled photoassimilates could be detected first in the nearest flower bud and leaf bud, lates supplied by each labeled leaf were first transported to nearby sinks, and that the sink organ receiving the photoassimilates from a source depended on the source-sink distance (Lacointe, 2000), with shorter distances being preferential (Cerasoli et al., 2004). Moreover, ${ }^{13} \mathrm{C}$-labeled photoassimilates exported from the labeled fifth leaf were found in the adjacent fruit $10 \mathrm{~d}$ after labeling, which was earlier than the time for the labeled third leaf because of the shorter distance between the source and sink, reconfirming that sinks were fed primarily by nearby sources. In addition, the level of ${ }^{13} \mathrm{C}$-labeled photoassimilates in flower buds was always greater than that in leaf buds at the same node position, indicating that the photosynthates were preferentially allocated to the main sink. When comparing the flower bud with the fruit, the fruit was always the main sink and had greater sink strength. Because the sink strength increases with fruit growth, fruit may import photoassimilates from other distant sources. Further studies of the effects of other sources on the levels of ${ }^{13} \mathrm{C}$-labeled photoassimilates in $C$. oleifera leaves allocated to the fruit will be performed. suggesting that the ${ }^{13} \mathrm{C}$-labeled photoassimi-
Formation and regulation of alternate bearing in $C$. oleifera. It is well-known that the distribution of photoassimilates in the growing process of crops are not balanced, and fruit always are the strongest sinks. In our study, more ${ }^{13} \mathrm{C}$-labeled photoassimilates were allocated to the fruit, and more fruit was produced during the on-crop year. Because many photoassimilates were consumed for fruit development, the remaining photoassimilates that can be used for flower bud differentiation would naturally decrease, resulting in little flower buds; therefore, there would be a sharp decline in the number of fruits during the next year (off-crop year). In citrus trees, although the girdling could block the downward translocation of photosynthates and metabolites through the phloem (Goren et al., 2003), high demand for carbohydrates by the developing fruit during the on-crop year caused no accumulated carbohydrates above the girdle ( $\mathrm{Li}$ et al., 2003), and the fruit load led to the inhibition of flowering after the heavy crop load in alternate bearing trees (Monerri et al., 2011). The mechanism of alternate bearing in pistachios was the abscission of fruit buds, which was correlated in time with the seasonal vegetative and reproductive cycles of pistachio, and bearing shoots produced lower seasonal carbon levels compared with nonbearing shoots (Marino et al., 2018).

The upper $C$. oleifera leaves (first leaf) on shoots supplied more assimilates to the bud, resulting in the upper buds differentiating into flower buds. Assimilates from the middle leaves (third leaf) translocated to the buds and fruit, and the middle buds formed either flowers or leaves. The basal leaves (fifth leaf) had an important role in feeding fruit and basal buds did not form flower buds. Therefore, the basal leaves should be retained for a high yield in the current year, and the top leaves should be retained for a high yield during the following year. Furthermore, the thinning of fruits during the on-crop year can promote flower bud formation and increase the yield of $C$. oleifera crops during the following year; however, during the offcrop year, more fruit should be retained to maintain the fruit yield and the thinning of middle-upper buds could promote more photoassimilates to allocate to the fruit. In addition, most of the lateral buds could differentiate into flower buds; therefore, we hypothesized that if there was no fruit on the shoot, then the basal leaf, as a source, could provide plenty of photoassimilates for the development of buds. As a result, the basal bud may differentiate into a flower bud.

Although two metabolic sinks (flower bud and fruit) of $C$. oleifera exist on the same plant at the same time, there are various ways to influence the levels of endogenous hormones that can affect the sink strength, such as pinching and the application of plant growth regulators, which, in turn, regulate the competition between buds and fruit Pinching removes the young parts of the shoots, sending more assimilates to the buds 
or fruits (Shi, 2017). The proper use of plant growth regulators can alter the ability of the plant to transport assimilates, resulting in the effective and proper allocation of photoassimilates to flower buds and fruit (Wen et al., 2015a, 2015b).

During this study, the dry matter accumulation in the flower bud was higher than that of leaf bud, which indicated that the flower bud had more photoassimilates. Furthermore, the dry matter accumulation in the first flower bud was always higher than that of the third flower bud, which coincided with the higher flower bud differentiation rate of the first flower bud compared to that of the third flower bud.

The oil conversion stage is a critical period of competition for ${ }^{13} \mathrm{C}$-labeled photoassimilates between flower buds and fruit. Sink strength changes dynamically (Fanwoua et al., 2014), and the major sink is different at different plant developmental stages. During our study, the most rapid growth period of $C$. oleifera was the oil conversion stage, during which ${ }^{13} \mathrm{C}$-labeled photoassimilates in the third and fifth leaves decreased at the fastest rate. Moreover, the level of translocation to the fruit kernel increased most notably during the oil conversion stage, which indicated that this period was crucial for kernel development as a consequence of the activated metabolism in fruit that requires raw material from which to synthesize lipids (Zhang et al., 2013). Furthermore, the greatest increase in the level of ${ }^{13} \mathrm{C}$-labeled photoassimilates in the first and third flower buds occurred between the rapid growth stage and oil conversion. Therefore, the oil conversion stage was the most competitive period and might affect both flower bud formation and fruit development.

\section{Conclusion}

Photosynthetic characteristics of C. oleifera leaves were influenced by the leaf position and fruit growth stage. The values of the photosynthetic parameters of the fifth leaf were always greater than those of the first and third leaves during the different fruit growth stages. The oil conversion stage had the greatest impact on photosynthetic parameters. Furthermore, the levels of photoassimilate translocation from different node source leaves were different, with photoassimilates from the upper leaves being mainly translocated to the adjacent flower buds, while the leaves in the middle translocated photoassimilates primarily to the buds and fruit, and the basal leaves mainly translocated photoassimilates to the fruit.

\section{Literature Cited}

Barzegar, T. and F. Nekounam. 2016. Plant sinksource relationships and carbon isotopic labeling techniques. Indian J. Plant. Physiol. 6:1617-1626.

Cao, W.X. 2011. Crop cultivation, 2nd ed. Science Press: Beijing, China.

Cerasoli, S., P. Maillard, A. Scartazza, E. Brugnoli, M.M. Chaves, and J.S. Pereira. 2004. Carbon and nitrogen winter storage and remobilisation during seasonal flush growth in two-year-old cork oak (Quercus suber L.) saplings. Ann. For. Sci. 61:721-729, doi: 110.1051/forest:2004058.

Chen, Y.Z., Z.H. Xiao, S.F. Peng, X.H. Yang, D.X. Li, X.N. Wang, and W. Duan. 2006. Study of fruit growing specialties and its oil content in oil-tea camellia. For. Res. 19(1):9-14.

Driever, S.M., T. Lawson, P.J. Andralojc, C.A. Raines, and M.A.J. Parry. 2014. Natural variation in photosynthetic capacity, growth, and yield in 64 field-grown wheat genotypes. J. Expt. Bot. 65:4959-4973, doi: $10.1093 / \mathrm{jxb} /$ eru253.

Evers, J.B., J. Vos, X. Yin, P. Romero, P.E.L. van der Putten, and P.C. Struik. 2010. Simulation of wheat growth and development based on organ-level photosynthesis and assimilate allocation. J. Expt. Bot. 61(8):2203-2216, doi: 10.1093/jxb/erq025.

Fanwoua, J., E. Bairam, M. Delaire, and G. Bucksorlin. 2014. The role of branch architecture in assimilate production and partitioning: The example of apple (Malus domestica). Front Plant Sci 5:338, doi: 10.3389/fpls.2014.00338.

Grappadelli, C.L., A.N. Lakso, and J.A. Flare. 1994. Early season patterns of carbohydrate partitioning in exposed and shaded apple branches. J. Amer. Soc. Hort. Sci. 119:596603, doi: 10.1007/BF00223650.

Greer, D.H. and C. Weston. 2010. Heat stress affects flowering, berry growth, sugar accumulation and photosynthesis of Vitis vinifera $\mathrm{cv}$. Semillon grapevines grown in a controlled environment. Funct. Plant Biol. 37:206-214, doi: 10.1071/FP09209.

Goren, R., M. Huberman, and E.E. Goldschmidt. 2003. Girdling: Physiological and horticultural aspects. Hort. Rev. 30:1-36, doi: 10.1002/ 9780470650837.ch1.

He, Y.H. 2010. Studies on photosynthetic characteristics of oil-tea Camellia clones at the fat conversation period of fruit. Dissertation, Central South University of Forestry and Technology.

Kositsup, B., P. Kasemsap, S. Thanisawanyangkura, N. Chairungsee, K.D. Satakhun, K. Teerawatanasu, T. Ameglio, and P. Thaler. 2010. Effect of leaf age and position on lightsaturated $\mathrm{CO}_{2}$, assimilation rate, photosynthetic capacity, and stomatal conductance in rubber trees. Photosynthetica 48:67-78, doi: 10.1007/s11099-010-0010-y.

Lacointe, A. 2000. Carbon allocation among tree organs: A review of basic processes and representation in functional-structural tree models. Ann. For. Sci. 57:521-533, doi: 0.1051/forest:2000139.

Lei, H., S.C. Su, L.Y. Ma, Y. Wen, and X.N. Wang. 2017. Molecular cloning and functional characterization of CoFT1, a homolog of FLOWERING LOCUS T (FT) from Camellia oleifera. Gene 626:215-226, doi: 10.1016/ j.gene.2017.05.044.

Lestari, R., G. Ebert, and S. Huyskenskeil. 2011. The effect of light and water supply on growth, net $\mathrm{CO}_{2}$ assimilation rate and mineral content of Salak (Salacca zalacca (Gaertn.) Voss) Seedlings. Intl. J. Biol. 3:94-104, doi: 10.5539/ ijb.v3n3p94.

Li, C.Y., D. Weiss, and E.E. Goldschmidt. 2003. Girdling affects carbohydrate-related gene expression in leaves, bark and roots of alternatebearing citrus trees. Ann. Bot. 92(1):137-143, doi: $10.1093 / \mathrm{aob} / \mathrm{mcg} 108$.

Liu, Y., T. Ge, Z. Zhu, S. Liu, Y. Luo, Y. Li, P. Wang, O. Gavrichkova, X. Xu, J. Wang, J. Wu, G. Guggenberger, and Y. Kuzyakov. 2019. Carbon input and allocation by rice into paddy soils: A review. Soil Biol. Biochem. 133:97107, doi: 10.1016/j.soilbio.2019.02.019.

Marino, G., M.L. Mantia, T. Caruso, and F.P. Marra. 2018. Seasonal dynamics of photosynthesis and total carbon gain in bearing and nonbearing pistachio (Pistacia vera L.) shoots. Photosynthetica 56:1-10, doi: 10.1007/s11099017-0752-x.

Monerri, C., A. Fortunato-Almeida, R.V. Molina, S.G. Nebauer, A. García-Luis, and J.L. Guardiola. 2011. Relation of carbohydrate reserves with the forthcoming crop, flower formation and photosynthetic rate, in the alternate bearing 'Salustiana' sweet orange (Citrus sinensis L.). Scientia Hort. 129:71-78, doi: 10.1016/j.scienta.2011.03.009.

Muller, B., F. Pantin, M. Ge'nard, O. Turc, S. Freixes, M. Piques, and Y. Gibon. 2011. Water deficits uncouple growth from photosynthesis, increase $\mathrm{C}$ content, and modify the relationships between $\mathrm{C}$ and growth in sink organs. $\mathrm{J}$. Expt. Bot. 62:1715-1729, doi: 10.1093/jxb/ erq438.

Myers, J.A. and K. Kitajima. 2007. Carbohydrate storage enhances seedling shade and stress tolerance in a neotropical forest. J. Ecol. 95(2):383-395, doi: 10.2307/4495991.

Osorio, S., Y.L. Ruan, and A.R. Fernie. 2014. An update on source-to-sink carbon partitioning in tomato. Front Plant Sci 5:516, doi: 10.3389/ fpls.2014.00516.

Preston, K. 1998. The effects of developmental stage and source leaf position on integration and sectorial patterns of carbohydrate movement in an annual plant, Perilla frutescens (Lamiaceae). Amer. J. Bot. 85:1695, doi: 10.2307/2446503.

Proietti, P., A. Palliotti, F. Famiani, E. Antognozzia, F. Ferrantib, R. Andreuttib, and G. Frenguellib. 2000. Influence of leaf position, fruit and light availability on photosynthesis of two chestnut genotypes. Scientia Hort. 85:63-73, doi: 10.1016/s0304-4238(99)00129-6.

Shi, B. 2015. Photosynthesis and assimilate distribution in source leaves in response to sink source manipulations in Camellia oleifera. Dissertation, Central South University of Forestry and Technology.

Shi, H.S. 2017. Causes for biennial fruiting of Camellia oleifera and cultivation measures. Anhui For. Sci. Technol. 43(1):32-34.

Sun, Z., Q. Chen, X. Han, R. Bol, B. Qu, and F. Meng. 2018. Allocation of photosynthesized carbon in an intensively farmed winter wheatsoil system as revealed by ${ }^{14} \mathrm{CO}_{2}$ pulse labelling. Sci. Rep. 8(1):doi: 10.1038/s41598-01821547-y.

Takai, T., M. Kondo, M. Yano, and T. Yamamoto. 2010. A quantitative trait locus for chlorophyll content and its association with leaf photosynthesis in rice. Rice 3:172-180, doi: 10.1007 s12284-010-9047-6.

Tustin, S., L. Corelli-Grappadelli, and G. Ravaglia. 1992. Effect of previous season and current light environments on early-season spur development and assimilate translocation in 'Golden Delicious' apple. J. Hort. Sci. 67:351-360, doi: 10.1080/00221589.1992.11516258.

Wang, R.H., J.C. Chang, K.T. Li, T.S. Lin, and L.S. Chang. 2014a. Leaf age and light intensity affect gas exchange parameters and photosynthesis within the developing canopy of field net-housegrown papaya trees. Scientia Hort. 165:365-373, doi: 10.1016/j.scienta.2013.11.035.

Wang, R., G.Q. Xie, Y.Z. Chen, S.F. Peng, X.N. Wang, X.H. Yang, L. Ma, L.S. Chen, and W. Tang. 2014b. Annual variation of chlorophyll content and soluble protein content of Camellia 
oleifera and their impact on net photosynthetic rate. Hunan For. Sci. Technol. 41:9-13.

Wang, X.N., L.J. Jiang, Y.Z. Chen, R. Wang, S.F. Peng, L.S. Chen, and L. Ma. 2011. Observation on morphological and anatomical characteristics of the flower bud differentiation on Camellia oleifera. J. Cent. South Univ. For. Technol 31:22-27, doi: 10.14067/j.cnki.1673-923x.2011.08.030.

Wen, Y., S.C. Su, L.Y. Ma, and X.N. Wang. 2018a. Effects of gibberellic acid on photosynthesis and endogenous hormones of Camellia oleifera Abel. in $1^{\text {st }}$ and $6^{\text {th }}$ leaves. J. For. Res. 23(5):309-317, doi: 10.1080/13416979.2018.1512394.

Wen, Y., S.C. Su, L.Y. Ma, X.N. Wang, and S.Y. Yang. 2015a. Effects of different concentrations of paclobutrazol on flower bud differentiation and fruit quality in Camellia oleifera. Acta. Agr. Univ. Jiangxinesis 37:1027-1032, doi: 10.13836/j.jjau.2015156.

Wen, Y., S.C. Su, L.Y. Ma, X.N. Wang, and S.Y. Yang. 2015b. Effects of gibberellins on flower bud formation and fruit quality in Camellia oleifera. J. Zhejiang Univ. Agr. For. 32:861867, doi: 10.11833/j.issn.2095-0756.2015.06. 006.

Wen, Y., S.C. Su, L.Y. Ma, S.Y. Yang, Y.W. Wang, and X.N. Wang. 2018b. Effects of canopy microclimate on fruit yield and quality of Camellia oleifera. Scientia Hort. 235:132-141, doi: 10.1016/j.scienta.2017.12.042.

Wu, Z.L., X.F. Tan, J. Yuan, and L.Y. Huang. 2016. Morphology and photosynthetic parameters of Camellia oleifera leaves at different ages. Nonwood For. Res 34:24-29, doi: 10.14067/j.cnki.1003-8981.2016.02.005.

Yuan, D.Y., F. Zhou, X.F. Tan, C.Y. He, J. Yuan, and X.M. Fan. 2011. Flower bud differentiation and development of male and female gametophytes in Camellia oleifera. J. Cent. South Univ. For. Technol 31:65-70, doi: 10.14067/ j.cnki.1673-923x.2011.03.025.

Yuan, J., B. Shi, Z.L. Wu, and X.F. Tan. 2015. Response of fruit quality and leaf photosynthesis to different sink-source relationships in
Camellia oleifera. J. Plant Physiol. 51:12871292, doi: 10.13592/j.cnki.ppj.2015.0297.

Zhang, C., K. Tanabe, F. Tamura, A. Itai, and S.P. Wang. 2005. Spur characteristics, fruit growth and carbon partitioning in two late-maturing Japanese pear (Pyrus pyrifolia Nakai) cultivars with contrasting fruit size. J. Amer. Soc. Hort. Sci. 130:252-260, doi: 10.21273/JASHS.130.2.252.

Zhang, L.Y., X.Y. Wang, and Y. Cao. 2013. Soluble sugar content and key enzyme activity and the relationship between sugar metabolism and lipid accumulation in developing fruit of $\mathrm{Ca}$ mellia oleifera. J. Beijing For. Univ. 35:55-60, doi: 10.13332/j.1000-1522.2013.04.023.

Zhou, C.F., X.H. Yao, P. Lin, and J. Lu. 2013. Growth characteristics and dynamic analysis of water and oil content on oil-tea camellia fruit. J. Yangzhou Univ 34:49-53, doi: 10.16872/ j.cnki.1671-4652.2013.03.012.

Zhuang, R.L. 2008. Camellia oleifera Abel of China, 2nd ed. China Forestry Publishing Press: Beijing, China. 